\title{
From labour contractors to worker-agents: Transformations in the recruitment of migrant labourers in India
}

\author{
Jayaseelan Raj and Richard Axelby
}

This article examines the circumstances, in which the tasks performed by professional labour contractors may be passed on to worker-agents. It does so by critically engaging with the experience of migrant workers from the eastern Indian state of Jharkhand as they travel to work in the Peermade tea belt in the south Indian state of Kerala. Specifically, we identify shifts in economic and political contexts that have permitted these functions to pass from labour contractors to workers-agents and from a sardari (top-down) to a ristedari (kinship based) system. Outlining the functions of the labour contractor - as bridge, broker and buffer - the article details the complex processes and the series of negotiations that occur during the transition from labour contractor to worker-agent-led recruitment and the implications of this shift for labour relations in the production setting. We conclude by calling for further consideration of the 'workeragent' as a key emerging figure in understanding the contemporary transformations in the reproduction of footloose migrant labour, which may have larger ramifications for other contexts in South Asia and beyond.

Keywords: migrant labour, labour contractor, worker-agent, plantation, India

\section{I}

\section{Introduction}

One chilly morning in early 2015, the usual tranquillity of the Hill View Estate in Kerala's Peermade tea belt was broken by the arrival of Thomas - a Syrian Christian from the valley town of Thodupuzha. For more than a year, Thomas had been making a handsome income by delivering migrant workers from Jharkhand to the AUBURN Company which owns the Hill View. Now, Thomas's position as a labour contractor-together with the income that came with it—was under threat. Bypassing the established Tamil workforce's homes, Thomas rushed straight to the line houses where his Jharkhandi workers had been staying. An argument ensued with accusations and counteraccusations thrown back and forth. Thomas 
threatened the workers of dire consequences - if their complaints continued, he would ensure that they never find work in Kerala again. Hearing this, the workers laughed, and a humiliated Thomas was roughly pushed out of the house. Those who had previously referred to him as saab (sir) were now abusing him, both verbally and physically. Though he did not yet know it, the workers he had recruited were now actively plotting to usurp Thomas's position as the supplier of migrant labour to the plantation.

To those familiar with circular or seasonal migration in India, Thomas is an immediately recognisable figure. The growing scholarly literature on labour migration properly recognises the contribution of professional sub-contractors (i.e. those who bid to perform a task and employ labourers to carry it out) and labour agents (who supply labourers to employers in return for a commission/fee). Mediating between labour and capital, these actors are central to the organisation of migration for work. This article, however, focuses on a third category of mediator - that of the 'worker-agent' - a figure, who supplements wages from manual work with a marginal commission paid by an employer or intermediary in return for recruiting others to the same work site. In contrast to professional contractors and labour agents, these worker-agents rely on kinship and friendship networks to find fellow workers to work alongside them. A number of studies have discussed the ways, in which migrant workers' friendship and kinship networks support migration (e.g. Carrier 1992; Bolt 2015; Barrientos 2013), but precisely how the event of worker-led recruitment unfolds within micro-level social contexts, remains unexamined. Furthermore, the processes of recruitment by professional labour contractors and by the workers themselves exist side by side in most of the narratives. In other words, in these accounts, one form of recruitment does not replace the other. This is contrary to the situation discussed here, where the labour contractor is replaced by the worker-agent, whose attempt to establish hierarchical relationship with the labourers is strongly resisted by the fellow workers. 
This article critically engages with the experience of migrant workers from the eastern Indian state of Jharkhand as they travel to work in the Peermade tea belt in the south Indian state of Kerala. ${ }^{1}$ Based on the ethnographic analysis of micro-level social contexts, it details the complex processes and series of negotiations that occur during the transition from labour contractor to worker-agent recruitment and the implications of this shift for labour relations in the production setting. One of the observations we make is of the dependence of workeragent-led recruitment on non-hierarchical, egalitarian sets of social relations. This is in contrast to professional labour contractors who also supervise and pay workers (Chakrabarty 1989; Chandavarkar 1994). Therefore, our worker-agents are quite different from the professional labour contractors, including the colonial kangani ${ }^{2}$ and $s a r d a r^{3}$, who depend upon a clear hierarchical division from recruited workers. We also observe that the 'decline of the regular worker' (Parry 2018: 5) is a major factor for the replacement of the hierarchical labour contractor by the egalitarian worker-agent, as well as for the maintenance of relations of relative equality between the workers and the worker-agents that recruit them. This is evident as we compare changes in the various functions-bridging, brokering and buffering - performed by different kinds of labour contractors.

\section{II}

\section{Migrant labourers and their contractors}

A growing scholarly literature has examined the drivers and patterns of internal migration in India and the conditions under which migrant labourers work (see Deshingkar and Farrington

\footnotetext{
${ }^{1}$ The research for this article was carried out in Kerala from 2014-16 (Raj) and in Jharkhand in 2016 (Raj and Axelby) and involved a combination of participatory observation, collection of genealogical histories of migrant families, and detailed interviews with workers, employers and contractors.

2 The term 'kangani' refers to the labour contractors-cum-supervisors - usually Tamils - who would recruit workers from their own regions.

${ }^{3}$ Labour recruiters-cum-supervisors.
} 
2009; Breman et al 2009; De Haan and Rogaly 2002). There are also detailed ethnographies on communities whose histories are significantly related to migrant labour. Breman (1985 and 1996), Mosse (et al 2002; 2005) and Breman et al (2009) have recognised the centrality of migration respectively in Gujarat, Madhya Pradesh and Tamil Nadu. Some understand migrants as part of a broader system of exploitation and oppression under capitalist production (Breman 1985 and 1996; Bourgois 1989); they also emphasise the unfree (neobonded), casual, and precarious nature of migrant labour (Guerin et al 2009; Raj 2014; Parry 2018). Others pay attention to the ability of workers to exercise forms of agency when negotiating the terms of their engagement (Lal 1989; Mosse et al 2002; De Neve 2014).

A key figure in South Asian labour migration is the professional labour contractor, who operates through formal as well as informal networks to facilitate the kinds of informal, temporary and flexible employment practices that have fuelled the Indian economic boom. Though there is no commonly agreed definition of labour contracting, it is generally associated with what the ILO (International Labour Organization) terms, a 'triangular employment relationship', in which the direct employer is differentiated from the person or company for whom work is carried out (Barrientos 2013). That this definition covers a range of sub-contracting possibilities is reflected in the variety of titles which attach to it: third-party labour contractor, recruitment agent, labour intermediary, gang-leader, and jobber. With regard to their role directing labour migration, contractors may appear as exploitative gangmasters (Breman 1985 and 2003) or as vulnerable and precarious brokers (Picherit 2009), who provide vital services to workers under their employers (Mosse 2005).

Historical accounts of labour recruitment to plantations and industrial towns have recognised the significance of kinship networks and the way the labour contractors used them to operate the chain of labour procurement (Carrier 1992; Heidemann 1992; Chandavarkar 1994). The literature also discusses the transformations in recruitment arrangements, for 
example, from the indentured to the Kangani system ${ }^{4}$. While the indenture system used a chain of officials and contractors in procuring labour, it was much more personalised and localised in the subsequent Kangani labour regime in which workers were commonly recruited from the same village as the kangani who used personal ties and regional solidarity with the workers to assert their authority (Raj 2014). This also resonates with the contemporary literature on the use of kin morality by the employer-cum-recruiters, as argued by Geert De Neve (2008) in the case of dyeing industry in Tamil Nadu. De Neve shows how the employers-cum-recruiters evoke moralities of kinship in the shop floor to inculcate a sense of commitment among the workers in order to secure a stable labour force. Such attempts become futile when the workers often choose other employers who pay them more, thus overriding the morality of kinship. At the same time, kin-like relations and obligations may develop within the workplace among migrant workers as a support system to deal with their alienation, as recognised by Bolt (2015) in the case of Zambian migrants to South African fruit farms. Bolt also examines how various forms of labour procurement exist side by side, including the personalised labour recruitment coordinated by black foremen. James Carrier (1992) discusses the way that family networks that had previously ordered work in cottage industries were reoriented to generate recruitment to English mills. Drawing on these historical and anthropological narratives, in this article, we develop the distinction between the labour contractors and the workers who recruit fellow workers. In particular, we draw attention to the forms of power, knowledge and authority they deploy, and the processes, by which, in the case of Kerala's Peermade tea plantations, one has replaced the other.

\footnotetext{
${ }^{4}$ See Heidemann (1992).
} 


\section{III}

\section{Bridge, broker and buffer: The functions of the labour contractor}

In scholarly literature, contractors appear variously as exploitative gangmasters (Breman 1985 and 2004) or as precarious middlemen (Picherit 2009) who are central to labour migration (Mosse 2005). Here we open up these binaries to consider how labour contractors fulfil three distinct but complementary roles - that of bridge, that of broker, and that of buffer.

\section{Bridge}

The ability of contractors to derive profit from organising migration lies in the inequalities of knowledge about possibilities in different sectors and regions. The 'bridge' aspect is most significant at the initial stage of the recruitment process, when workers are unaware of new sources of employment and employers are unaware of the availability of labour (Kooiman 1977). Contractors can offer knowledge about reliable workers to potential employers while at the same time providing workers with information about employment opportunities (Mosse 2005). This aspect of the contractor's role is underpinned by acts of translation: organising travel to distant locations and arranging shelter, food and employment for migrants in unfamiliar locations, and with people who do not share a common local language. Thus, a contractor is able to maintain their position, space and status by mediating knowledge over employment possibilities. ${ }^{5}$ But, if we accept that the contractor's role is to facilitate the initial connection of capital and labour, then, once relations are established, we would expect the

\footnotetext{
${ }^{5}$ Among historians of capitalist agriculture labour contracting is seen to play a crucial part in the early development of rural labour markets (Brass 2004: 316). Following the idea of a dual-economy model, contractors provide the bridge that links workers in the low-paid traditional agricultural sectors to employers in advanced industrial and capitalist agriculture sectors. The logical conclusion of this argument is that once capitalist agriculture has established itself 'the labour contractor then simply vanishes from the historical stage' (ibid.). This is not a view to which Brass himself subscribes. To him: 'the role of the gangmaster is a systemic one, reproduced by capitalism itself' (ibid. 321).
} 
contractor to no longer be required. To ensure their longevity, this initial 'bridging' role must be combined with other functions.

\section{Broker}

After the initial stage, a contractor must maintain their position by mediating between the demands of labour and capital. Success depends on continually attracting and retaining a reliable supply of workers which can be managed to meet employers' variable demands for migrant labour. Navigating concentrations of production in manufacture and seasonality in agriculture, labour contractors must be able to match the peaks and troughs in demand which local labour markets are unable to manage. Barrientos describes how labour contracting serves the needs of contemporary capitalism by reducing the transaction costs of finding and recruiting appropriate workers at the right time and maximising the efficiency of labour use on an 'as need' basis (2013: 1066). Turning to their workers, a contractor must strike a balance between rates of pay sufficiently attractive to maintain recruits, while low enough to undercut labour markets in the receiving locality and also to extract a profit from the operation. Contractors maintain supply using a range of inducements including credit and advances against future work. Contractors also utilise uncertainty and precarity to stifle protests and bind workers to them — only by conforming will workers gain future employment opportunities (Breman 2003). However, managing demand and supply of labour is a delicate balancing act: in those markets subject to periodic peaks and troughs, the labour contractor's position is highly vulnerable.

The major difference between the 'bridge' and the 'broker' roles is that the former is the key in the early stage of migration while the latter aspect gains prominence when there is a need to manage supply in accordance with the production requirements of a given period. 
However, as the third and final function reveals, there is more to the role of the contractor than being just a neutral 'finding-agency' for labour.

\section{Buffer}

Brass writes of labour contracting as working to 'maintain or improve control over (and thereby cheapen the cost of) their workers by means of coercion' (2004: 315-16). Here, we see how labour contractors serve a third function that is highly conducive to capitalist production relations - that of a buffer, by which employers are able to maintain some separation from workers. There is a degree of ambiguity about the position of workers delivered to an employer by a contractor; and the ultimate employer is able to exploit this ambiguity in a number of ways. The opaque nature of the relationship between employers and workers benefits the former at expense of latter by allowing them to avoid legal requirements over-pay, conditions of employment and social provisions (Barrientos 2008: 982). Breman talks of migrant workers as being 'outside of the law [and] beyond the benign reach of state agencies'; this makes them particularly vulnerable to 'repression and exploitation in a capitalist framework remarkable for its nakedness and rawness' (2003: 284). This distancing of the ultimate employer soothes out potential resistance and allows for the engagement of migrant workers on a casual basis, in which workers are denied the labour rights that would normally be due to them.

\section{A precarious balance}

The performance of labour contracting is a function of the types of labour and commodity markets which they serve. As such, the relative importance of the different elements - the balance of bridge against broker against buffer - is determined by the position of workers, the 
needs of employers and the wider legal and political context. Each of these facets of the contractor's function also depends on the deployment of particular kinds of knowledge. As bridge, the contractor must have knowledge of potential workers and potential employers; as broker, they must use their knowledge of labour markets to meet peaks and troughs in the supply and demand for labour; the performance of the buffer role requires the obscuring of information-keeping knowledge both from the workers themselves and from those seeking to assist workers in claiming their legal entitlements.

The position of labour contractor is not inevitable and permanent. We explore here the circumstances, in which the labour contractor becomes dispensable. While labour contractors may be important in establishing contact between workers in one location and employers in another, in the ethnographic case we relate in this article, the contractor is only a temporary conduit that ultimately is replaced by another figure - that of the worker-agent. To understand the respective roles of workers and contractors, we must situate them properly in the complex economic and social realities, in which they operate. The next section looks at the transformation over time of the types of relationships — both vertical and horizontal—which facilitate migration out of villages in Dumka District in the eastern Indian state of Jharkhand. We do so by first offering a survey of migration history, household economy and social relations in a village, which we will call Jharatti, which lies north of Dumka town, close to the border with Godda District.

\section{IV}

\section{The significance of migration in Jharkhand's Dumka District}

Ashok Rana, a 50-year-old migrant worker, was standing proudly outside his newly built concrete family home in Jharatti village when we visited him. The house's construction had taken three years and had cost about 500,000 rupees. Inside, there was a TV and a music player, while outside rested the shiny new motorbike, which formed part of the marriage 
dowry for Ashok's eldest daughter. How was Ashok Rana able to afford all this in a region, where the average daily wage for unskilled labourers was less than 150 rupees per day? The kutcha (unpaved) road in front of Ashok Rana's house connects to a metalled rural lane, which leads to a well-built highway, which is further linked to the national rail network at Jasidih Junction. For more than 20 years, Ashok Rana has followed this well-trodden route, initially to Kashmir to build mountain roads, and more recently — accompanying his wife and sons - to Kerala, where they work on tea plantations. The knowledge gained over this period had now allowed Ashok to upgrade his role as a migrant worker to combine it with organising the migration of others. Jharkhand, one of the newer states of the Indian Union, came into existence in November 2000, when the erstwhile bigger state of Bihar was bifurcated. Located in the north-east of Jharkhand, the District of Dumka lies in the broad and undulating strip of hilly country that separates West Bengal from Bihar. This area of Jharkhand stands in dramatic contrast to the rich agricultural plains of the neighbouring states. In earlier centuries, Dumka was thickly forested; though this has been steadily lost-first to submergence with the damming of the Mayurakshi river in the 1950s, then to mining with the huge Rajmahal coal mine project conceived in the early 1980s, and more recently, through the open-cast gravel mining that blights whole swathes of the countryside. Despite the vast mineral wealth lying beneath their feet, the people of Dumka remain among the very poorest in India. In Dumka, 93 per cent of the population remains rural, and the average literacy rate stands at 61 per cent according to the 2011 Census of India (Government of India 2011). In 2006, the Indian government listed Dumka amongst the country's 250 most backward districts. ${ }^{6}$ The designation of the area as a 'backward region' is so rooted that it often figured in our discussions with the migrant workers: their experience of moving away from home in search

6 'Riders for NREGA: Challenges of backward districts.' Available at http://nrega.nic.in/Planning_Commision.pdf. Accessed on 26 January 2019. 
of work allows them to offer the informed opinion that Jharkhand is 'the poorest state in India'.

There are 148 households in Dumka's Jharatti village-39 Muslim, 58 Santal, 20 Lohars, and the rest a mixture of service castes. Of these 148 households, slightly more than half report having family members who migrate seasonally to find work in other states. In the past, the mainstay of the local economy in Dumka District was agriculture. The Santals and the Lohars, who make up the majority of the population in Jharatti village, continue to hold small sizes of land - three to five acres for a typical family — on which they are able to grow one crop of rice or corn. Demographic growth has meant that landholdings are getting increasingly fragmented. While most of these families grow enough rice to be self-sufficient, there are a few, who manage to produce a surplus for sale. Those families, who own no land, may provide labour for transplanting rice and for cutting the harvest, but this agricultural labour is available for less than 60 days each year, and the rates of pay-130 rupees for women workers and 150 to 200 rupees for men-are low.

Farmers in Jharatti spoke of declining rainfall and the fall in the level of the water table that have made irrigation unaffordable. They described the presence of kala patthar (black rock) and of ground having become hot and hard, which prevented rain water from percolating. In the words of one informant: 'Barish nahi to kheti nahi, to kya kareh?' (Without rain, there is no farming, so what to do?). In truth, alternatives are limited. Local opportunities for unskilled manual labour-building houses, baking bricks or constructing roads - pay no more than agricultural work. No one reported getting any of the 100 days of work which the NREGA (National Rural Employment Guarantee Act, 2005) ${ }^{7}$ scheme guarantees. Nor have those who belong to the Scheduled Tribes been able to gain the

7 'The National Rural Employment Guarantee Act (MNREGA).' Available at http://nrega.nic.in/rajaswa.pdf. Accessed on 01 February 2019. 
government jobs supposedly reserved for them. Out of the slightly more than 700 adults who inhabit Jharatti, there is only one who is a teacher, and three others, who have joined the police. For most people in Jharatti, the only source of income is selling their labour on a short term, casual basis. Each day, a few men from Jharatti might walk or cycle to the bazaar (market) in Dumka town. Here, they would stand in a junction near the bus stand hoping that a mistri (the main worker) will select them for some construction work. This may pay a little more, in some cases, as much as 230 rupees per day, but is not available on a regular basis, and not at all during the monsoon months. In short, the lack of local employment opportunities, divided landholdings, declining rainfall, falling groundwater level, and higher wages in other regions, have combined to create a situation, in which seasonal migration has become the primary source of income for many families.

Roy (2008), Rao (2006) and De Haan (2002) have described migration out of the erstwhile bigger Bihar, as having a history dating back at least 100 years. In the late $19^{\text {th }}$ century, people were leaving the hills and jungles of Chotanagpur to work on railway and road-building projects in West Bengal and Burma, mills in Bombay, and in tea plantations in Assam. Adivasi workers from this region had also migrated to the colonial plantations in the Caribbean, Fiji and South Africa (Roy 2008). Rogaly et al (2003) recount how since colonial times, farmers from West Bengal travelled to Jharkhand to recruit seasonal labour. A more recent migration stream took large numbers of male workers from Jharkhand to India's Himalayan borders, where they were employed by the General Reserve Engineer Force (GREF) to build roads. A range of other opportunities have drawn workers away from Jharkhand in recent decades; in Jharatti, we found people who had found temporary employment in the construction sector in Delhi and Bangalore, had processed meat in Pune, served in dhabas (roadside restaurants) in Ladakh, and worked in textile factories in Surat. 
More recently, employment in Kerala's tea plantations has opened up a new niche for seasonal employment.

Decisions, of when to migrate and for which kinds of work, reflect certain aspects of ascribed identity (De Haan and Rogaly 2002). Young unmarried men go to build roads, and groups of women led by a senior male relative might do agricultural work in West Bengal. However, our village survey of Jharatti showed that across ethnic, caste and religious groups, the proportions of households, for whom migration forms part of their household economy, remain relatively consistent: across Muslim, Santal and Lohar households, a figure of 50 per cent is maintained. Men are more likely to migrate than women. Those who migrate might be landless but are equally likely to own land.

Conversations in Jharatti revealed that migration is facilitated by a range of kinship ties - collateral, marital and affinal-but also through non-kin ties of friendship and association. Randall Kuhn (2003) has described how rural-urban migration in Bangladesh has created forms of social exchange for which 'identities that had little meaning in the local context are mobilised to foster new and important relationships' (2003: 312). Rogaly et al suggest similar processes are at work in Jharkhand: 'As people interact with others from distant places, they move away from the narrower, within-group, identifications characteristic of village life' (2003: 308). We would agree that migration has created a collective identity, that of the Jharkhandi migrant labourer, that functions above and beyond affiliations of caste, religious or ethnic differences to enable potential workers to find work and a place to live. Certainly, it was not considered unusual for individuals from different social groups to form a collective 'community of migration', able to travel, live and work together. Broad affinities to a Jharkhandi migrant identity shape relations between workers and are deployed instrumentally when interacting with employers. 
The varied sectors and locations, in which work may be found, derives from, and in turn contributes, to the store of knowledge about nation-wide job markets that has accumulated at the village level: information circulates between villagers, opportunities are noted, experiences compared, and new possibilities generated. Bound up with ties that are formed in the village, colonies of Jharkhandi labourers-whether in Kerala, Kashmir, Bombay or Gujarat — share common senses of identity and store of knowledge but also a of a moral relationship that places great emphasis on equality and solidarity.

In the next section, we look in greater detail at circular migration from Jharkhand to the tea estates of Kerala. Here, we focus on the arrival of migrant labourers to the tea plantations of Peermade and explain the role of intermediaries in facilitating their employment. Examining in turn the respective positions of migrant workers, professional labour contractors, worker-agents and the management of the tea company, we are able to evaluate the manner, in which forms of knowledge work to shape recruitment arrangements.

\section{$\mathbf{V}$}

\section{The rise and fall of the labour contractor in Kerala's Peermade tea belt}

Known as the 'tea pot of Kerala', Peermade is one of the most important tea producing regions in South India: 36 individual estates cover 10,000 hectares in the Western Ghats. Tea plantations were first established in the area in the $1860 \mathrm{~s}$, when colonial bureaucrats and merchants realised the potential for large-scale cash crop cultivation in the Western Ghats. Initially to convert forest area into plantations and then to pluck and process tea leaves, workers, from 'untouchable' castes, were recruited from the Tamil speaking region of South India through a system of indenture. The recruitment of fellow Tamils was made easier by the long history of migration from this area to plantations in other parts of the world such as Sri Lanka and South Africa. Under the Kangani system, potential recruits would be offered an 
advance which was made against wages they could earn from future labour (Guilmoto 1993). Once at the plantations, they had to work under the strict class order. The workers were divided into labour gangs under the Kangani who recruited them and was now responsible for supervising and paying them. The labour gangs worked for Kanganis as the wage was directly paid by Kangani. Thus, Tamil Kanganis in the Peermade tea belt played the role of perfect mediator who acted as a bridge and broker between the plantation company and the workers. A similar system operated in the plantations of north-east India though in that areas upper-caste Bengali supervisors were called 'sardars' and mainly recruited a workforce of Adivasis from the highlands of Nepal and the Chotanagpur plateau (Roy 2008). In some respects, this Kangani/Sardari system — based on ties formed in the site of recruitment—could be claimed as the predecessor of the current worker-agent. However, the contemporary worker-agents introduced in this article combine their recruitment activities with manual wage labour alongside those they recruit. The contemporary worker-agent therefore lacks the authority and supervisory status that Kanganis and Sardars were accustomed to in the past.

Tamil dalits and their descendants formed the majority of the labour force in Kerala's tea belt for over a century. Then, in the early 1990s, a severe economic crisis crippled the tea industry in India. The downturn was triggered by competition from Kenya and Sri Lanka and by the loss of Indian tea market in Russia and Iraq following the collapse of the USSR and the Gulf war respectively. Many plantations were closed; and in those that survived, the crisis provided a pretext for companies to reduce wages and withdraw the relatively generous social provisions their workers had previously enjoyed. Plantations' closures and stagnating wages forced many workers to seek employments outside of the tea industry. Although they still form the majority of the labour force, their presence in the tea belt has undergone a drastic decline: in the case of the Hill View estate, the number of permanent workers fell from 1100 in the late 1980s to just 232 only two decades later. Consequently, when the estate returned to 
normal functioning by the beginning of 2011, they faced a significant shortage of labour. To resolve the shortage of labour, especially for the plucking of tea leaves, attempts were made to (re)hire retired and temporary workers from crisis-ridden estates nearby. But a few former Tamil workers were willing to return as casual labourers - aware that they would get no social security benefits - for daily wages of Rs 189 . The company needed new sources of labour; it was found in East and Central India.

\section{A bridge that charges toll at both ends}

By the end of 2011, migrant workers from central and eastern India began to arrive to take up work in the plantations of Peermade. Assamese Muslims formed the majority of the new migrant workforce for the KABS and CMT tea companies, while workers from Odisha were recruited into smaller estates producing tea, coffee and cardamom. However, it was migrant workers from Jharkhand - approximately 200 men and women from Dumka and Godda districts - who came to form the majority of the workforce of the AUBURN company. Of the 72 families from Jharkhand working in the AUBURN's three estates, we will here concentrate on the 30 families plus another 12 individuals (a total of 57 workers) who were working at AUBURN's Top View estate during the early part of 2015.

It was Thomas - the Syrian Christian contractor from the valley town of Thodupuzha-who first brought these Jharkhandi workers to the AUBURN company. Thomas had been introduced to the manager of AUBURN by a member of the managerial staff, who was his long-term friend. The Company instructed Thomas to recruit 100 workers without preference for the ethnicity or social origin of the workforce. Using the connections he had established with Syrian Christian missionaries in Jharkhand, Thomas initially brought in around 40 workers from Jharatti in Dumka District and from the village of Sakri over the border in Godda District. For each worker he delivered to the plantation, Thomas received a 
commission besides the reimbursement of his expenses on food and transportation of the workers. In addition to this, the plantation company paid Thomas a commission of Rs 20 per worker per day. This, apparently, was not enough. Thomas negotiated an agreement with the management that the migrant workers' wages should be transferred directly to his bank account every month, allowing him to distribute the payment to his workers. From these minimum legal wages, Thomas now subtracted a further Rs 20 commission for himself, leaving the daily pay passed on to the workers at just Rs 169. As a bridge, Thomas connected two sides and charged tolls at both ends.

The double commission that Thomas was able to generate derived from his ability to mediate between employers and workers. At a social level, Thomas had friendships with individuals serving in management positions at the tea company. From these connections, Thomas would have gained an understanding of the economics of tea production, and, once alerted to their need to hire new workers, of how much they would be willing to pay for it. Thomas's knowledge of Jharkandi potential workers was of a different order. Introduced to them by some fellow Syrian Christians, Thomas understood that these people from rural Jharkhand were prepared to work for low rates of pay. To Thomas, 'Jharkhandi migrants' were all of one class: a homogenous mass of workers available for easy exploitation. The biggest problem Thomas faced was ensuring that these workers stayed long enough at the plantation to make his efforts worthwhile - the stereotypical Jharkhandi was unreliable and known for absconding for home when they were most needed at the plantation.

After having recruited the migrant workers, Thomas showed little interest in their activities or needs once they reached Kerala. Thomas travelled to the plantation only to distribute the wages — seldom regularly - to the workers. Sometimes, the workers had to wait 
even for two months to receive their pay. ${ }^{8}$ A Tamil worker, whom we interviewed, told us that 'it was like a festival day for the migrant workers, when they saw Thomas coming with their money'. Thomas used 'delay in payment' as a means to control workers: those who left the plantation early went unpaid. However, because he rarely visited the plantation, he understood little of the problems arising there.

The role of labour contractor to the Hill Top estate provided Thomas with a handsome income. However, despite the tables seemingly being stacked decisively against the Jharkhandi workers, Thomas's position as a contractor was less secure than he anticipated. Once it was discovered that Thomas was extracting a 'dual-commission', his authority (trust) with workers was lost. The workers complained to a Tamil employee called Anthony. Sympathetic to the migrant workers, Anthony communicated their complaints to the field officer and also to the manager of the estate. At first, the manager told the migrant workers that there is an agreement between the company and Thomas, which could not be broken. However, the workers continued to raise their concerns and finally threatened to leave the plantations unless Thomas was taken out from the role of mediation. With Thomas's duplicity now made public, the company risked alienating the labour force they had come to rely upon since losing their Tamil workers. Thomas was quickly cut off_-deemed expendable by the company. Reneging on their 'gentleman's agreement', the manager of the Hill View estate told Thomas that he could no longer act as contractor with the excuse that he did not meet the legal requirement of being registered with the Labour Office in the Peermade tea belt. Thus, Thomas was abandoned by both, the migrant workers and the company. Thomas's super-exploitation of the migrant workers and overconfident sense of indispensability resulted in his downfall.

\footnotetext{
${ }^{8}$ Each week, the company gave each worker an advance of Rs 150 to cover expenses. This 'store cash' (in Tamil, chelavukasu) would be deducted from their monthly wages paid to Thomas.
} 
Losing Thomas, the mediator, created a vacuum. This was to be filled by the figure of the worker-agent, who met the requirements of — bridge, broker and buffer-by mediating between the needs of workers and employers in new ways. In the next section, we look at some of the individuals, who took on the role of worker-agent, and consider how different forms of knowledge came to constitute the basis for the recruitment and retention of the migrant workforce.

\section{Knowledge, trust and the worker-agent}

After Thomas's exit, the company was concerned about the difficulties in recruiting new labourers to the plantations. The migrant workers themselves proved to be the answer to the company's problem. The first individual to take up the possibility to step into the contractor's shoes was Sagar - a Santali from Jharkhand's Godda District, who had been brought to Hill View by Thomas. Sagar told us, how in February 2013, the company management had approached him with the offer of a bonus for each additional worker he recruited to the plantation. After a short visit back to Jharkhand, Sagar returned with 16 new workers including his wife, his sister's husband and his nephew. His reward was a payment of Rs 5 per person for each day they remained on the plantation. But Sagar was not satisfied with the commission the company gave him. Concerned that Sagar might pull out his workers and move them to another estate, the company responded in two ways. In October 2014, the company upped the commission with an offer of Rs 7 per day per worker plus a one-off payment of Rs 1000 to cover the costs of food and transportation. The company also devised a strategy of extending this offer to other worker-agents. When the company made this new offer, two of Thomas's recruits-Rooplal and Ramadhar-stepped in promising to the company to bring in more workers. Rooplal, a 40-year-old college dropout, jumped at the means to make more money. Unlike Rooplal, 50-year-old Ramadhar had never been to 
school; but he had good village-level connections having served on the community council in the village. Within a week of company's announcement of the offer, both Rooplal and Ramadhar travelled to their native villages to recruit additional workers. Rooplal brought in nine workers while Ramadhar brought in 11 - mostly relatives and friends. The fourth migrant worker who took the chance to act as a worker-agent was Ashok Rana, who had kin living in Sakri too. In a series of interviews with these four individuals, we learned more about the shift from the sardari (chief-led) to the ristedari (kinship-based) model of recruitment. In all these interviews, much emphasis was placed on the importance of particular forms of knowledge that underpinned the performance of their new roles as worker-agents.

A look into the history of labour migration out of Jharkhand shows that the importance of labour contractor in other forms of circular migration tends to weaken over time. Heidemann (1992), Das Gupta (1992), and Sen (2010) document shifts from vertical systems of recruitment to horizontal friendship/kinship-based arrangements. In the initial stages, the contractor holds a monopoly of knowledge about receiving destination, the forms of work available, and the terms of conditions that may be negotiated. This would certainly seem to be true in the case of Thomas and the migrant workers he brought to the Hill View estate. Initially Thomas's role as bridge and broker was reinforced by the Jharkhandi workers' unfamiliarity with plantation work in Kerala and ignorance of Tamil or Malayalam. However, over time, these migrant workers were able to acquire knowledge about the very different social and linguistic settings of the Peermade Tea belt. ${ }^{9}$ Ten months after their

\footnotetext{
${ }^{9}$ Venkiteswaran (2017) describes the sharing of jokes and gossip among migrant workers leaving Kerala to return home to Odisha and Bengal. Communicated through social and kinship networks, these migrant narratives stereotype the Malayalees' obsession with personal cleanliness and general aversion to manual work. These same networks have facilitated the spread of valuable knowledge about the tea production process, the administration of the plantations and job availability.
} 
arrival, the likes of Ashok Rana, Ramadhar, Rooplal and Sagar had acquired knowledge of the needs, negotiating strategies and trustworthiness of the tea company. Though never as indepth in their understanding as Thomas, this knowledge was enough to engage with the individual managers. The acquisition of these particular types of knowledge allowed workeragents to begin to negotiate with potential employers about the supply of migrant labour to the plantations.

The role of professional labour contractors such as Thomas also depends on the accumulation of knowledge about their workforce. Here, worker-agents have an advantage: their knowledge being innate to their social network, they are better able to maintain the supply of labour to companies through an awareness of who wants or needs work, who is likely to work well, and who can be depended upon to be reliable. In contrast to professional contractors, worker-agents possess wide and deep knowledge of the economic and social situation in home villages - they know who has land and who does not (and what this means for seasonal availability); they are also able to differentiate the balance of occupations within each household (and thus the degree, to which fellow villagers are dependent on maintaining some income from working on the plantation). Knowledge of the family backgrounds of potential workers (marital status, dependents and their ages) is another means by which their reliability can be judged. This social knowledge even extends to whether a marriage is a happy one. In one story we heard, a wife demanded that her husband come with her to Kerala because she started doubting that he might have been having an affair.

Another significant distinction between worker-agents and professional labour contractors is that the former continue with manual work alongside those they have recruited. As such, they remain integrated in the kinship/friendship network that supports them and forms the basis of the system of recruitment. Worker-agents, unlike the professional contractors, are more likely to have the knowledge of the problems in the personal lives of 
the workers and can make attempts to help them. Furthermore, social expectations based on long-standing relations established back in the village could be used to persuade the recruits not to leave and remain as 'ideal' workers. Compared with the crude withholding of wages by the professional contractor, the worker-agent's knowledge of social context provides a subtler and more sophisticated tool to ensure conformity and commitment. As worker-agents live and work alongside those whom they recruit, they are more responsive to labour issues than the distant Thomas living in the valley town of Thodupuzha. However, initially at least, the worker-agents struggled to know who to communicate these problems to. However, once a new management structure was implemented (the Tamil Anthony was appointed as a gobetween), the lives of the migrant workers improved with more regular payment of wages and advances to buy food and warm clothing.

The transition from professional contractor to worker-agent is described as a shift from the sardari system to ristedari system of recruitment. To put it another way, Thomas's hierarchical relationship as professional labour contractor was replaced by a horizontal system conditioned by kinship and friendship network. Although Ashok Rana, Sagar, Rooplal and Ramadhar became, in effect, recruitment agents, neither the company nor their fellow workers viewed them as sardars who must be obeyed. The individuals who took on the role of worker-agent were, for the most part, respected members of their communities. Consequently (and again in stark contrast to Thomas), while they might accept a commission from the company, it would be viewed as a social transgression to take the same from their fellow workers, who were also friends and family. In a way, those who have close links with the workers are more likely to be successful as recruiters. They are also more likely to get the balance right between support and exploitation, which Thomas had fatally miscalculated. Since the worker-agents continued to be workers, they were able to project themselves as part of the exploited Jharkhandi migrant community unlike Thomas, who was viewed as an 
exploiter. However, it appears that there existed, from the start, soft conflicts among the worker-agents to become the dominant recruiter. Using their own connections to assert their own dominance, this competition within the worker-agent group required them to maintain relatively decent relations within the migrant workforce. Thomas, being the only agent, was able to act as a saab or sardar. But the rise of worker-agents resulted in democratisation of the relation between the recruiter and the recruited.

It is instructive to consider what happens on those rare occasions when a workeragent has tried to become a dictator like Thomas. We were told by other workers that Sagar, after his initial success, started to refer to himself as sardar. This was followed by an accusation on him, of sexual harassment of a migrant woman. Consequently, although Sagar continued to bring immediate family members to the plantation, those who were not so close to him opted to transfer over to worker-agents such as Ashok Rana, whose own social networks overlapped with their own. Such transitions were mediated by the representative of the plantation management. The same horizontal knowledge system that underpinned wideranging recruitment networks both depend upon and maintain an egalitarian structure where trust ensures loyalty and commitment. Those who try to rise above it to become contractors (like Sagar) are cut down.

\section{VI}

\section{Optimal ignorance and knowledge: The benefits for the company}

Having outlined the contrasting manner, by which professional labour contractors and worker-agents manage to supply labour to the Peermade tea estates, our attention now turns to the management of the plantations, to consider their motivation in accepting shifts in systems of recruitment. Initially, the recruitment of Jharkhandi migrants through professional contractors such as Thomas appealed to the plantation companies for a number of reasons. First, the new migrant workers were cheap; they were prepared to accept the minimum wage 
rates that the previous Tamil workforce had largely rejected. Furthermore, being employed on temporary bases, they were not entitled to the same social security and welfare measures that were available to the Tamils, who were directly and permanently employed by the company. The need for plantation labour spikes twice a year-during the peak plucking seasons_-from January to March, and August to October. Second, the supply of labour can be matched to these twin peaks without the need for workers to be kept on in the slack intervening months. That the flow of Jharkhandi workers could be turned up or down according to demand was hugely important to the companies. Having the contractor as a buffer, the workers could be easily abandoned in the event of a crisis in future.

The third motive for using Thomas as an intermediary-and the one that largely explains the first two-is that doing so allowed the plantation company to ignore legal rights supposedly due to all workers. By using contractors as intermediaries, employers are able to avoid legal responsibilities to labour, for example, the implementation of The Plantations Labour Act ${ }^{10}$ of 1951. Legally, casual labour can be used only to fulfil tasks outside the daily routine of the plantations, for example, cutting of trees. In fact, Jharkhandis of both sexes were engaged in tea plucking; men were also employed in routine 'factory' work such as filling tea leaves into large drums for the crushing machines and carrying the processed tea to the packaging area. Using the contractor as a buffer, plantation companies were able to deny to their migrant labourers 'permanent worker' status and accompanying benefits including provident fund access, paid annual holidays and medical leave. On any of these grounds, the recognised trade unions and government officials (such as Inspector of Plantations, and Deputy Labour Officer) could have intervened in support of the casualised migrant workforce. They chose not to do so. Trade unions in the tea belt are rarely concerned about

10 'The Plantations Labour Act, 1951.' Available at https://labour.gov.in/sites/default/files/The-Plantation-Labour-Act-1951.pdf. Accessed on 31 January 2019. 
the exploitative situation of the new migrant workforce, and the benefits of membership have not been extended to the casual migrant workforce.

Initially at least, the plantation companies were happy with this arrangement - with Thomas as an intermediary, they hoped that to ensure a reliable supply of workers, for whom further employment required them to remain compliant. However, while neoliberal conditions contributed to the initial creation of the niche exploited by Thomas, what happened at the Hill View plantation confirms De Neve's view that the same conditions ultimately 'tend to undermine rather than enhance contractors' entrepreneurial success and to reduce rather than intensify their power vis-à-vis both capital and workers' (De Neve 2014: 1306).

Why did the company agree to shift from contractor-led recruitment to make arrangements via worker-agents? The immediate cause was a concern that following their falling out with Thomas, the migrant labourers might quit the plantation and return to Jharkhand. The company quickly recognised that it is preferable to negotiate with multiple worker-agents than with a single contractor like Thomas. Furthermore, the worker-agents' superior understanding of the situation of potential workers and their extended social networks in recruiting areas mean that they are able to respond to changes in demand, and deliver a reliable supply of workers. Even better, as far as the company was concerned, these new recruitment agents were largely unfamiliar with the kinds of bargaining strategies used by employers when negotiating rates of pay. No longer reliant on a single contractor, the company could spread risks while reducing labour costs (compare the Rs 7 per worker per day paid to worker-agents to the Rs 20 per worker per day paid to professional contractors). The Jharkhandis were better and cheaper than Thomas, and could recruit new labourers quickly and easily. Moreover, one might assume that the worker-agents would side with their fellow Jharkhandis the event of a dispute, but in actuality, individual worker-agents were 
reluctant to challenge the company for the fear of being sidelined or dismissed. For the company, the figure of the worker-agent has come to play a vital role in the ongoing making and remaking of labour markets.

While the rise of worker-agents provided many advantages for the plantation company, the absence of a professional contractor did expose new tensions in the relationship between the workforce and the company. Previously, the professional contractor would represent the workers and raise their concerns with the management. The company did not want to parley with worker-agents in the same way-to do so would threaten the class order within the plantation. The increasing casualisation of work is supported by the complex mechanism of labour recruitment devised by the tea company; new layers of management handle the outsourcing of labour recruitment to worker-agents while simultaneously reducing the power of these agents to bargain on behalf of the workforce. The AUBURN company chose to refigure the labour hierarchy on the Hill View estate by deploying the Tamil Anthony to act as a mediator between the new migrant workforce and the field officer of the estate. Previously, Thomas would have to be contacted every time the company wanted to make a decision over the workers' situation. Now, without upsetting the plantation hierarchy, the workers' concerns and complaints and the company's decisions could be communicated directly to the Hindi-speaking Anthony. On their arrival to the plantation, Anthony would take charge over the new workers, helping them to settle in the plantation. Through Anthony, it was agreed that the company would pay an advance to buy groceries, warm clothes and the tools needed for work. ${ }^{11}$ By appointing an informal liaison officer, the company denied further status and power to worker-agents, preventing them from gaining knowledge about

11 The company has arrangements with various shops in nodal towns, from which workers can purchase groceries and other necessary things for the first month. However, to do so, they must be accompanied by a supervisor, who is required to approve the items and the bill. The amount spent is deducted from workers' wages over the next four or five months. 
company's economic interests, and discouraged them from organising the workers against the company. Anthony was fondly called mama (maternal uncle) by the migrant workers; the company cleverly exploited this close relationship and the workers' vulnerability to exert control over the new labour force.

\section{VII}

\section{Conclusion: From labour contractor to worker-agent}

In this article, we have seen how the organisation of migration to Kerala's tea estates has changed from a hierarchical contractor-led system of recruitment to one in which workeragents bring friends and family to work with them in the plantations. The figure of the worker-agent in the migration dynamics has to be understood, not as an offshoot or parallel system of labour recruitment, but as a major system that potentially replaces the professional contractors/commission agents.

With worker-agents becoming able to quickly mobilise a reliable workforce, their deployment allows tea companies in Peermade to manage levels of demand for labourers without having to employ workers on permanent basis. The shift to a ristedari recruitment system widened the company's recruitment strategies while allowing them to remain distant from the casual workforce and its representatives. In other words, the balance of knowledge and ignorance was optimised in favour of the employer and against the worker-agents and temporary migrant workers. These transformations have important implications for the bridging, brokering and buffering functions of labour recruitment as demonstrated in Table 1:

Table 1: Comparison between professional labour contractors and worker-agents

\begin{tabular}{|l|l|l|}
\hline \multicolumn{1}{|c|}{ Role } & \multicolumn{1}{|c|}{ Labour contractors } & \multicolumn{1}{c|}{ Worker-agents } \\
\hline Bridge (facilitating & Based on asymmetrical & Since contact has already been \\
initial contact & knowledge: workers and prime & made, the worker-agent has no \\
between workers and & employers are unaware of one & role in introducing the two \\
employers) & another; professional contactors & parties. Instead, the worker \\
& know the terms of employment & agent's role comes from \\
& offered by companies and the & continually maintaining the \\
\hline
\end{tabular}




\begin{tabular}{|c|c|c|}
\hline & $\begin{array}{l}\text { willingness of labour to work for } \\
\text { them. }\end{array}$ & bridge. \\
\hline $\begin{array}{l}\text { Broker (maintaining } \\
\text { flexible supply of } \\
\text { labour to meet } \\
\text { varying demands of } \\
\text { employer) }\end{array}$ & $\begin{array}{l}\text { 1. Supply of labour: The } \\
\text { professional contractors use } \\
\text { networks created professionally. } \\
\text { They need to accumulate } \\
\text { knowledge of the workforce to } \\
\text { maintain the supply of labour. } \\
\text { 2. Maintaining labour: } \\
\text { Contractor is not located at place } \\
\text { of work and lacks awareness of } \\
\text { social relations of workers. } \\
\text { 3. Contractor maintains control } \\
\text { through economic coercions, } \\
\text { such as withholding wages and } \\
\text { arrears and refusing to provide } \\
\text { further employment } \\
\text { opportunities to those who try to } \\
\text { leave without his consent. } \\
\text { 4. Company-friendly operator. } \\
\text { The priority is always the } \\
\text { company. The professional } \\
\text { contractor is not a threat to the } \\
\text { company. } \\
\text { 5. Cost is high }\end{array}$ & $\begin{array}{l}\text { 1. Supply of labour: Worker- } \\
\text { agent have a superior ability to } \\
\text { maintain supply of labour } \\
\text { through extended social } \\
\text { networks (awareness of who } \\
\text { wants/needs work). Their } \\
\text { knowledge is innate to their } \\
\text { social network. } \\
\text { 2. Maintaining labour: Worker- } \\
\text { agent maintains control over } \\
\text { workers through social } \\
\text { expectation, which extend back } \\
\text { to the village. A subtler and } \\
\text { sophisticated form of control } \\
\text { compared to that of the } \\
\text { professional contractor. } \\
\text { 3. Company appoints an } \\
\text { informal liaison officer to work } \\
\text { alongside worker-agent to keep } \\
\text { the worker-agent away from } \\
\text { acquiring further status and } \\
\text { power, and also from organising } \\
\text { the workers against the } \\
\text { company. } \\
\text { 4. Cost is low }\end{array}$ \\
\hline $\begin{array}{l}\text { Buffer (allowing } \\
\text { employers to avoid } \\
\text { legal responsibilities) }\end{array}$ & $\begin{array}{l}\text { Professional contractor is the de } \\
\text { jure employer-has } \\
\text { responsibility for workers and } \\
\text { pays their wages. Allows } \\
\text { company } \\
\text { responsibilities. to }\end{array}$ & $\begin{array}{l}\text { Following crisis-company has } \\
\text { greater freedom to violate or } \\
\text { ignore employment legislations } \\
\text { and regulations. Rights are } \\
\text { commonly denied to all staff } \\
\text { (whether permanent or casual, } \\
\text { local or migrant). No need to use } \\
\text { contractors as a buffer to avoid } \\
\text { responsibilities. }\end{array}$ \\
\hline
\end{tabular}

Source: Authors

Looking at the different aspects of the contractors' role - as bridge, broker and buffer-we can see how changes in the relative positions and needs of labour and capital contribute to the 
process, by which contractors are replaced by worker-agents. We have shown how shifts in recruitment systems illustrate certain features of contemporary global capitalism that relies on the continuous creation of a precarious casual labour force. In some small ways, the shift away from contractor-led recruitment has benefitted the migrant workers, who are paid more regularly and are able to communicate problems more easily; more substantial benefits have accrued to the worker-agent who commands a bonus payment from the labour of fellowmigrants. But the biggest winner has proved to be the plantation companies-with the bridging role established, the use of worker-agents instead of professional contractors has resulted in lower overall costs, the securing of a flexible and reliable supply of labourers, and the continued denial to casual workers of their legal dues. It may be possible that in the horizontal social networks that facilitated the rise of the worker-agents, there exist the possibility for political struggle and collective negotiation to further improve the position of migrant labour. This can be helped in a stronger way if the existing trade unions and government labour officials intervene. However, this seems unlikely for now.

\section{Acknowledgements}

The research was funded by an EU ERC Starting Grant and a UK ESRC grant awarded to Alpa Shah as Principal Investigator (ERC-2012-StG_20111124'The Underbelly of the Indian Boom: Adivasis and Dalits' and ESRC ES/ K002341/1 'An Ethnographic Investigation into the Persistence of Poverty among Adivasis and Dalits in India.

\section{REFERENCES}

Barrientos, S. 2008. "Contract Labour: The "Achilles Heel" of Corporate Codes in Commercial Value Chains.' Development and Change 39 (6): 977-90. 2013. "Labour Chains": Analysing the Role of Labour Contractors in Global Production Networks.' The Journal of Development Studies 49 (8): 1058-71. 
Bolt, Maxim. 2015. Zimbabwe's Migrants and South Africa's Border Farms. Cambridge: Cambridge University Press.

Bourgois, Philippe. 1989. Ethnicity at Work. Baltimore: John Hopkins University Press.

Brass, Tom. 2004. “"Medieval Working Practices”? British Agriculture and the Return of the Gangmaster.' The Journal of Peasant Studies 31 (2): 313-40.

Breman, Jan. 1985. Of Peasants, Migrants, and Paupers: Rural Labour Circulation and Capitalist Production in West India. Delhi: Oxford University Press.

- 1996. Footloose Labour: Working in India's Informal Economy. Cambridge: Cambridge University Press.

- 2003. The Labouring Poor in India: Patterns Of Exploitation, Subordination and Exclusion. Delhi: Oxford University Press.

—2004. The Making and Unmaking of an Industrial Working Class: Sliding down to the Bottom of the Labour Hierarchy in Ahmedabad, India. Amsterdam: Amsterdam University Press.

-2010. Outcast Labour in Asia: Circulation and Informalization of the Workforce at the Bottom of the Economy. Delhi: Oxford University Press.

Breman, Jan., I Guérin, and A. Prakash, ed. 2009. India's Unfree Workforce: Of Bondage old and new. Delhi: Oxford University Press.

Carrier, James G. 1992. 'Emerging Alienation in Production: A Maussian History.' Man 27 (3): $539-58$.

Chakrabarty, Dipesh. 1989. Rethinking Working-Class History: Bengal, 1890-1940. Princeton: Princeton University Press.

Chandavarkar, Rajnarayan. 1994. The Origins of Industrial Capitalism in India. Cambridge: Cambridge University Press.

Das Gupta, Ranajit. 1992. 'Plantation labour in colonial India.' The Journal of Peasant 
Studies 19 (3-4): 173-98.

De Haan, Arjan. 2002. 'Migration and Livelihoods in Historical Perspective: A Case Study of Bihar, India.' The Journal of Development Studies 38 (5): 115-42.

De Haan, Arjan and Ben Rogaly. 2002. 'Introduction: Migrant Workers and Their Role in Rural Change.' The Journal of Development Studies 38 (5): 1-14.

De Neve, Geert. 2008. “"We are all Sondukarar (relatives)!": Kinship and its Morality in an Urban Industry of Tamilnadu, South India.' Modern Asian Studies 42 (1): 211-46.

- 2014. 'Entrapped Entrepreneurship: Labour Contractors in the South Indian Garment Industry.' Modern Asian Studies 48 (05): 1302-33.

Deshingkar, Priya and John Farrington. 2009. Circular Migration and Multilocational Livelihood Strategies in Rural India. New Delhi: Oxford University Press.

Gardner, Katy and Filippo Osella. 2003. 'Migration, Modernity and Social Transformation in South Asia.' Contributions to Indian Sociology 37 (1 and 2): v-xxviii.

Government of India. 2011. Primary Census Abstracts: Census of India. New Delhi: Office of the Registrar General and Census Commissioner, India, Ministry of Home Affairs, Government of India.

Guerin, Isabelle, A. Bhukut, K Marius-Gnanou, and G Venkatasubramanian. 2009. 'Neobondage, Seasonal Migration and Job Brokers: Cane Cutters in Tamil Nadu.' In India's Unfree Workforce: Of Bondage Old and New, edited by J. Breman, I. Guerin and A. Prakash, 233-58. New Delhi: Oxford University Press.

Guilmoto, Christophe Z. 1993. 'The Tamil Migration Cycle, 1830-1950.' Economic and Political Weekly 28 (3-4): 111-20.

Heidemann, Frank. 1992. Kanganies in Sri Lanka and Malaysia: Tamil Recruiter-cumforeman as a Sociological Category in the Nineteenth and Twentieth Century. München: Anacon. 
Kooiman, Dick. 1977. 'Jobbers and the Emergence of Trade Unions in Bombay City.' International Review of Social History 22 (3): 313-28.

Kuhn, Randall. 2003. 'Identities in Motion: Social Exchange Networks and Rural-Urban Migration in Bangladesh.' Contributions to Indian Sociology 37 (1 and 2): 311-37.

Lal, Deepak. 1989. The Hindu Equilibrium, Volume 2: Aspects of Indian Labour. Oxford: Clarendon Press.

Mosse, David, Sanjeev Gupta, Mona Mehta, Vidya Shah, Julia fnms Rees and KRIBP Project Team. 2002. 'Brokered livelihoods: Debt, Labour Migration and Development in Tribal Western India.' The Journal of Development Studies 38 (5): 59-88.

Mosse, David. 2005. 'On the Margins in the City: Adivasi Seasonal Labour Migrants in Western India.' Economic and Political Weekly 40 (28): 3025-38.

Parry, Jonathan. 2018. 'Introduction: Precarity, Class, and the Neoliberal Subject.' In Industrial Labor on the Margins of Capitalism: Precarity, Class, and the Neoliberal Subject, edited by Chris Hann and Jonathan Parry, 1-38. Oxford: Berghahn Books.

Picherit, David. 2009. “WWorkers, trust us!”: Labour middlemen and the rise of the lower castes in Andhra Pradesh.' In India's Unfree Workorce: Old and New Practices of Labour Bondage, edited by Jan Breman, Isabelle Guérin and Aseem Prakash, 259-83. Delhi: Oxford University Press.

Pieke, F.N. 1999. 'Introduction: Chinese migrations compared.' In Internal and International Migration: Chinese Perspectives, edited by Frank N. Pieke and Hein Mallee, 1-26. Surrey: Curzon Press.

Raj, Jayaseelan. 2014. 'Burden of Stigma: Crisis, Identity and Alienation in a South Indian Plantation Belt.' PhD diss., University of Bergen, Norway. 
Rao, Nithya. 2006. 'Power, Culture and Resources in Gendered Seasonal Migration from Santal Parganas.' In Poverty, Gender and Migration, edited by Anupama Roy and Sadhna Arya, 129-50. Delhi: SAGE Publications.

Rogaly, Ben, Daniel Coppard, Kumar Rana, Abdur Rafique, Amrita Sengupta, and Jhuma Biswas. 2003. 'Seasonal Migration, Employer-Worker Interactions, and Shifting Ethnic Identities in Contemporary West Bengal.' Contributions to Indian Sociology 37 (1-2): $281-310$.

Roy, Thirthankar. 2008. 'Sardars, Jobbers, Kanganies: The Labour Contractor and Indian Economic History.' Modern Asian Studies 42 (5): 971-98.

Sen, Samita. 2010. 'Commercial Recruiting and Informal Intermediation: Debate over the Sardari System in Assam Tea Plantations, 1860-1900.' Modern Asian Studies 44 (1): $3-28$.

Venkiteswaran, C.S. 2017. 'Of Migrants and Mindsets: A Train Journey Unravels the Experiences of Migrant Workers in Kerala.' Economic and Political Weekly 52 (6): 68-69. 